\title{
MUSICAL RESOURGES IN THE RUTGERS UNIVERSITY LIBRARY
}

\author{
BY CHRISTOPHER WILKINSON
}

Mr. Wilkinson is a graduate student in music at Rutgers

1

$1 \mathrm{HE}$ collection of resources of music in the Rutgers University Library is of considerable importance. Preserved in Special Collections, it consists of manuscripts and printed material from the early eighteenth century and music published in this country before the Civil War, as well as more modern publications that appeared in limited editions. Copies and prints of compositions, hymnals, tutors of singing, sheet music for the piano, histories of music and musical dictionaries make up the bulk of the collection. Though many of these sources have reappeared in more modern editions or, with justification perhaps, have faded into oblivion, the fact remains that the collection contains much of interest and it is the purpose of this report to survey it and pause to comment upon some of its more noteworthy parts.

By far the most significant holdings consist of compositions by George Frideric Handel preserved both in hand copies and prints. As a detailed study of this material has already appeared on the pages of this journal by Professor Martin Picker of the Department of Music, Rutgers College ("Handeliana in the Rutgers University Library," JRUL 29:I [December 1965]), a brief inventory of it should suffice.

During the composer's life and for several years after his death, much of his music was preserved in copies made by his personal amanuensis, John Christopher Smith, and men Smith had hired for that purpose. In the library, there are eleven volumes of Handel's music in copies made in part by scribes of Smith's group containing anthems for the Duke of Chandos and the Chapel Royal, a set of "Italian Duettos and Trios," and An Ode for Queen Anne's Birthday. On the occasion of a brief visit to Rutgers, the Danish musicologist and Handel scholar, Jens Peter Larsen, examined these volumes and confirmed Professor Picker's conclusions that of the entire 
set, one volume and the greater part of another were in the hand of "S IO," the tenth scribe of the Smith group, and that more than half of a third volume was copied by "S 9." It was the result of Larsen's work several years previous that the different handwritings of the Smith scribes were distinguished from one another and these sigla were devised by him to indicate the various anonymous individuals.

The compositions in print appeared during Handel's lifetime as well as in the course of the thirty-one years following his death in I 759. The earliest prints, of operas, were published between I 725 and 728 by J. Cluer of London. Of the six works, Admetus, Richard ye first, Rodelinda, Scipio, Serse, and Alexander, all but the last were first editions. Two groups of six concertos for harpsichord or organ published by John Walsh of London between I 740 and I 750 are preserved in a single volume. There are twenty-two additional compositions published by two firms, William Randall and $\mathrm{H}$. Wright, between 1769 and I790, among them Acis and Galatea ( I 769), the Dettingen Te Deum ( I 769), Esther (I 783), as well as three editions of Messiah.

Other musical publications of the eighteenth century, while not so rare, are nevertheless significant components of the collection. In the year I 776, there appeared the first of what eventually came to be a four volume work by Dr. Charles Burney, A General History of Music. It is an unusual history in many ways. It had no predecessor in the English language of comparable dimensions and was in fact intended to fill the need for a history of music in our language. Its author went to great lengths to gather material, including traveling to European libraries to examine personally the manuscripts of earlier compositions. At the same time, it is filled with the author's personal, frequently derogatory comments on the music of previous centuries. Burney was devoted to the contemporary music of his time and, caring little for earlier masters, was disdainful of their accomplishments. With this in mind, the modern student will find much of value in his writing. His preference for the "modern" musical scene resulted in much discussion of composers and performers of the second half of the eighteenth century who have since been forgotten and about whom we would know almost nothing, but for $A$ General History and Burney's other writings. 
The edition belonging to Rutgers is a handsome one still in the original binding; the four volumes appeared between 1776 and I 789. Like several of the other titles in the collection, it has appeared recently in facsimile. To this writer, an original edition has qualities not found in a modern reprint despite the greater accessibility of the latter.

Another genre of musical writing is the music dictionary. Rutgers has two examples, one from the I 730's, the other from the beginning of the last century. For the music historian, an early dictionary is valuable as it gives insight into the current attitudes toward musical styles, forms, and vocabulary of an earlier period. Terms which have either undergone a radical change of definition or have disappeared altogether may be found with appropriate definition in these early publications. The earlier of the two dictionaries in our collection is by Johann Gottfried Walther; the second is by Heinrich Christoph Koch. Walther's Musicalisches-Lexikon (Leipzig I732) is rich in information concerning music of the Baroque period. As it contains definitions of terms and brief biographies of musicians held in high esteem by its author, the Lexikon represents a valuable resource on the nature of music not only at the time of publication, but also for many years prior to that time.

Koch's dictionary, with the same title as Walther's, serves a similar function for the eighteenth century that the earlier source does for the seventeenth. Published in Offenbach am Main, near Frankfurt, in I 802, Koch's Lexikon is a useful source of information on music of the Classic period.

Another type of musical resource is represented in the Rutgers collection by a publication appearing in the same year as Koch's dictionary. While the study of the music of cultures other than that of Europe and its offshoots, has attracted much attention only in the twentieth century, isolated accounts appeared earlier. One example is a German translation of a study by Sir William Jones. Ueber die Musik des Indier (On the Music of the Indies) is a comprehensive study of Asian musical culture. In a very methodical manner the author explores the music of Arabia, Persia, India, China, and Polynesia, but in so doing, he reveals a prejudice, perhaps unconscious, for the music of his own culture.

One of the basic lessons which a student of ethnomusicology needs 
to learn is that care must be taken not to impose attitudes and standards upon the music of another culture. The music of India or China, for example, should be evaluated only in terms of those cultures and their standards. In the West, the diatonic, twelve-tone octave is the foundation of musical thought, reinforced by the writings of successive generations of theorists and by the countless number of compositions based upon it. Any student of non-western music seeking to evaluate the art of an alien culture is bound to find that the music is at odds with the traditions and practices with which he is familiar and may be tempted to question its artistic quality as a result. Sir William was a victim of this pre-disposition to western musical thought and his solution to the problems posed by compositions based upon scales other than the diatonic was to "correct" them to fit the musical framework of the West. He provides several examples of eastern music adjusted to his taste. In one instance an "Indian song with Sanskrit text" appears in the key of A major, in another a "Spring Song from China" is cast in D major.

It is noteworthy that this study was once part of the personal library of the eminent musicologist, Professor Curt Sachs. Dr. Sachs had a variety of interests. A student of both western and non-western music, he also was interested in the more specialized field of organology, the study of the types and characteristics of musical instruments, and was the author of one of the most authoritative dictionaries on this subject: Real-Lexikon der Musikinstrumente. From his collection, Rutgers has also acquired a nineteenth-century study of Indian instruments: Sir Sourindro Mohun Tagore's Short Notices of Hindu Musical Instruments (Calcutta I 877). This is but one of several books on instruments in the special collection.

The largest part of the collection is devoted to American music from the eighteenth and nineteenth centuries. It may be divided into several categories: tutors on singing, hymnals, sheet music, and song sheets. The small volumes designed to teach the singing of sacred music were intended either for self-instruction, as in the case of Andrew Law's The Rudiments of music or A Short and Easy Treatis on the Rules of Psalmody (I783), or for the instruction of children. This was the purpose of Elam Ives' Manual of instruction in the art of singing (183I). The author, no doubt with an eye on his compe- 
tition, assures his readers that the technique in his manual is both "strictly inductive and practical."

The collection of hymnals suggests that there were many publications of this type in America before the Civil War and that often revised editions of the same collection would appear only a year apart. Thomas Hastings and Solomon Warriner were responsible for one important collection: Musica sacra or the Springfield and Utica collections united. According to Gilbert Chase, this hymnal first appeared in 1816 and went through numerous editions up to 1836 (America's Music [New York r955], p. I6I). Rutgers possesses copies of two editions: the third of $\mathrm{I} 822$ and the fourth of 1823 . Another hymnal from the following year is also in the collection: The Musical Cabinet or Nerw Haven collection of sacred music . . . compiled and arranged by Alling Brown (New Haven I824). A third collection published in Utica, New York, as was the Musica sacra, dates from 1836 .

In terms of numbers, the bound volumes of sheet music constitute by far the largest part of the musical holdings. Though time did not permit an exhaustive examination of the entire uncatalogued collection, more than a dozen volumes were studied with an eye to contents, purpose, and approximate date of collection. We may define "sheet music" as consisting of short compositions printed on a single "sheet" of paper, for keyboard, voice with piano accompaniment, or piano and another instrument such as violin, flute, or oboe. The music discussed here is predominantly vocal music with piano accompaniment published up to the end of the Civil War.

The individual compositions were collected and bound into volumes either by the publisher or at the request of the owner of the individual compositions. Judging by the presence of indications of fingerings appearing in pencil in a number of the pieces, it can be assumed that they served as exercises for piano instruction. On the flyleaf of a volume belonging to one Rebecca M. Gillis appear the names of more than twenty ladies; one might speculate that they were students of hers at one time or another.

One can learn much about the popular music of the nineteenth century by examining these volumes. Not only is the music itself significant, but also the subject of the various song texts and the na- 
ture of the musical setting. Bearing in mind the importance of amateur music-making in this country before the invention of the radio and phonograph, we can learn a great deal about the nature of musical performances from these anthologies. For example, in a set of "Celebrated Instruction for the Piano-Forte," by F. Hunten, we can see the importance of piano duets (two performers on a single keyboard) as he included several sets of compositions for piano fourhands performance. If it is recalled that composers from Mozart to Brahms and beyond composed works specifically for this type of performance and that piano four-hands arrangements of other compositions were in abundance, this is not so surprising. Today, except for performances by professional pianists, the art of playing piano duets has all but died out.

The songs in the collections are, like all popular music, of topical interest and in a simple style. The sentimental texts intended to move the sensitive listener seem today to be ridiculously saccharine. Others were meant to inspire patriotic thoughts or to praise noble exploits. At least two songs salute the bravery and courage of Major General Zachary Taylor at the Battle of Buena Vista where, in 1847 , he defeated the far larger Mexican forces under Santa Anna. Other compositions are piano arrangements of marches; one published in 1847 was dedicated to Captain Stewart of Newark, New Jersey.

A large part of the strictly instrumental music was intended for dancing. Two "Favorite Waltzes" by Mozart appear side by side with polkas from the late I 840's. To sell one such dance, the social pretensions of the customer were appealed to as an ethnic curiosity, "The Spanish Polka" ( I 847), was touted as having been played by "Shaw's and Cameron's Band at Newport."

Another large portion of the music consisted of songs from various minstrel shows which traveled across the country and which presented the latest popular music. One of the leading minstrel groups was led by George N. Christy: The Christy Minstrels. Many of their songs in pseudo-Negro dialect made their way into these collections with piano accompaniment. Two individuals who composed music for such shows have left their mark on American music to this day; Dan Emmett's best known song, "Dixie," appears in one volume as does one by Stephen Foster. "The Voice of By-Gone Days," a popular song 
in 1850 when it first appeared has since been eclipsed by another of Foster's published the next year: "My Old Kentucky Home."

Serious music also made its appearance in these collections, but with far less frequency than the popular genres. In one volume a march from Rossini's cantata Moisé in Egitto (1818), appears; in another, a potpourri of melodies from Verdi's $I l$ Trovatore. It is a testament to the genius of the composer that this medley appeared in this country just three years after the opera's premiere in I 853 . Whereas some arrangements reflect a taste for Italian operas, one was a tribute to that country's outstanding violinist of the last century whose reputation extended far beyond the range of his travels. "Le Carnival de Venise d'àpres [Niccolò] Paganini: Capriccio pour le Piano" by Charles Voss, published in Philadelphia, testifies to the legendary skill of Paganini by its suggestions of virtuosic violin music.

A final, and far smaller, part of the American music material is at the same time the most problematic in terms of its original purpose: this is a group of song sheets. A song sheet consists of nothing more than the title and text of a popular song without any indication of the music to which it is to be sung. Such sheets as preserved at Rutgers cover the forty years from the Civil War to the turn of the century. Like those of the sheet music, the texts cover a variety of subjects. One of the earliest described with high praise the accomplishments of "Our Yankee Monitor," the ironclad battleship of the Union, which "At Hampton Roads ... the Merrimac chased away." The song continues with various statements regarding the impact this ship will have on international relations, for all nations, ". . . must build [John] Ericson's Iron batteries." It ends with the hope that, "When North and South is [sic] united, we'll have a happy land."

Equally fervent and as blind to the difficulties of resolving human conflicts is a song from near the end of the century. Entitled simply "I90I," it foresees in that year the realization of a number of goals, the last concerning the status of Ireland: "You can bet your sweet life we'll see Ireland free, in Nineteen Hundred and One." Other songs laugh at the temperance movement: "They all do it"; celebrate the Union Army: "Marching through Georgia," or salute new forms of transportation: "Riding on the Elevated Road." 
It is hard to know all of the purposes of the song sheets. As many carry the information that the music for the song is available from a certain publisher, clearly they were meant as advertisements. At the same time they might have served simply as additional copies of the text for those who wished to sing along, knowing the tune but not all of the words. Many of the sheets in the Rutgers collection appear to have been at one time bound into a volume, as indicated by the ragged left margins they now possess. Conceivably they were collected by people who used them in the course of an evening's musicale around the piano.

This study has not by any means exhausted the variety and depth of the musical materials in the Rutgers Library. Nothing has been said about the modern facsimiles of Byzantine manuscripts to be found there, for instance, nor about the limited editions of the twentieth century. Examples of most of the kinds of sources have been cited, and it is to be hoped that this report will encourage others to explore the collection further. 